\title{
Cetacean By-Catch in the Korean Peninsula-by Chance or by Design?
}

\author{
Douglas Craig MacMillan • Jeonghee Han
}

Published online: 19 October 2011

(C) Springer Science+Business Media, LLC 2011

\begin{abstract}
Whaling remains one of the most contentious issues in global conservation. In South Korea, where commercial and subsistence whaling are both illegal, domestic sales of cetacean products such as skin, blubber and red meat are allowed if they are accidently caught. However, environmental groups have claimed that the high price of meat may be acting as an incentive for illegal hunting and 'deliberate by-catch' where whales are intentionally killed or left to die by fishermen when they become trapped in their nets. In this paper we investigate the issue of deliberate by-catch and illegal hunting of the protected Minke J-stock population in Korean waters using grounded theory, an approach that allows theories and understanding to emerge from the analysis of both qualitative and quantitative data. Our research suggests that deliberate bycatch is almost certainly taking place but that illegal hunting and/or illegal importation from Japan may be far more significant sources of Minke whale meat. We discuss possible measures to reduce incentives for deliberate bycatch and illegal hunting such as the introduction of mandatory reporting of quantities supplied and consumed in restaurants and a tax on meat sales at auction. More generally, our research illustrates how the analysis of price movements can shed light on the scale of illegal wildlife trade and how a combination of both qualitative and quantitative methodologies can provide understanding of a complex, multifaceted conservation issue.
\end{abstract}

Keywords Minke whale-By-Catch $\cdot$ South Korea $\cdot$ Illegal trade Conservation

D. C. MacMillan $(\bowtie) \cdot J$. Han

University of Kent,

Canterbury, UK

e-mail:dcm@kent.ac.uk

\section{Introduction}

Bycatch, the unintended capture and killing of non-target species, is one of the greatest threats to endangered cetaceans (Lewison et al. 2004) with estimated annual global mortality rates of between 307,753 (Read et al. 2006). By-catch refers to non-target species accidently caught in fishing gear, but in this paper we investigate the possibility that whales are being deliberately killed through drowning and other means, and disguised as by-catch.

Our study focuses on the cetacean by-catch in South Korea (the Republic of Korea), a country where whaling for commercial gain is illegal, but domestic sales of by-caught whale products are allowed. The population at risk is the protected Common Minke J-stock, (Balaenoptera acutorostrata) which differs from the more abundant and unprotected O-stock in terms of geographic range, body size, conception dates, and genetic characteristics such as mitochondrial DNA haplotype frequencies (Goto and Pastene 1997; Baker et al. 2006). Although the IWC scientific committee has yet to decide the conservation status of the J-stock, the population may be as low as 900 individuals (IWC 1997) and possibly declining due to excessive by-catch among other factors (Baker et al. 2010; Wade et al. 2010).

Although these figures are disputed, the high incidence of cetacean by-catch in South Korean waters (accounting for $33 \%$ of global large cetacean mortality from by-catch (IWC 2009)), including an average of over 80 Minke per year in the last 10 years, suggests to conservationists that current laws, which allow by-caught whale meat to be sold into the restaurant trade, provide a strong incentive for deliberate drowning or killing by some other means and environmental NGOs have called for a trade ban on all Korean whale meat (Greenpeace International 2005; KFEM 
2005). The South Korean government seems ambivalent on the issue, in part because the scientific data on the J-stock is weak but also because the sale of by-caught cetaceans can provide significant income to hard-pressed Korean fishermen. Hence, there is little enthusiasm to introduce adaptations to fishing gear or techniques that have proved successful in reducing cetacean by-catch elsewhere (Trippel et al. 1999; Hall et al. 2000; Barlow and Cameron 2003).

Cetacean by-catch in South Korea is under-researched and poorly understood. Previous studies have focused on exploring biological and technical aspects of by-catch (An et al. 2010a; Song et al. 2010), and there has been no attempt to explore the issue with fishermen and other key stakeholders. In part, this is understandable because of the sensitivities of gathering data connected to illegal activities (Morizur et al., 1999; Lopez et al. 2003), but it means that the problem is largely tackled from a science-conservation perspective.

The aim of our paper is therefore to gain a better understanding of the scale and extent of deliberate by-catch in South Korea by combining qualitative data generated from interviews with fishermen, local businessmen and police officers with an analysis of empirical data that exists such as market prices, fishing effort, whale abundance and other indicators. This approach, where qualitative and quantitative data collection proceeds in tandem with analysis, to develop theory and understanding is known as grounded theory (Strauss and Corbin 1998) and is especially useful for complex conservation conflicts characterised by unreliable and/or insufficient datasets, high stakes, or potential sensitivities over clandestine activities (MacMillan and Phillip 2010) .

\section{Whaling}

\section{Culture and Conservation in South Korea}

Whaling in South Korea dates back to prehistory, with petroglyphs at Bangudae, drawn sometime between the New Stone Age and the Bronze Age, depicting men whaling (Hwang and Moon 1984; Ulsan Metropolitan City 2003). Modern commercial whaling began with foreign whalers from the USA, Russia, and Japan from the midnineteenth century and records from this period indicate an abundance of large whale species including Blue whale (Balaenoptera musculus), Fin whale (Balaenoptera physalus), Humpback whale (Megaptera novaeangliae), and Gray whale (Eschrichtius robustus). Commercial whaling by Korean fishermen began in 1946 after national liberation from Japan.

In 1986, in accordance with the IWC moratorium, the South Korean government banned whaling, with clear guidelines describing what constituted illegal activities including the use of guns or harpoons, the intentional killing of a live whale and the possession, storage, transportation, trading or exporting of illegally killed whale products (Ministry of Food, Agriculture, Forestry, and Fisheries 2009). Violation of these guidelines could result in a fine ranging from 2 million to 20 million Korean Won (US\$2,000 to US\$20,000), and/or imprisonment for up to 3 years. Fishermen are legally allowed to land cetacean as bycatch only when it is found dead (e.g., in their nets) and live animals entangled in nets must be released. On landing, bycaught whales are visually inspected, sometimes with the help of a metal detector, by the Korean Coast Guard (KCG) to determine if a whale has been deliberately killed by violent means (such as harpooning). The regional prosecutor determines the legality of by-catch based on these reports (Kim 1999).

The high level of cetacean by-catch in Korean waters has allowed a thriving business and culture based on the consumption of whale meat to develop, concentrated in the east coast cities of Pohang, Ulsan, and Busan. The town of Jangsaengpo in Ulsan, which was the biggest commercial whaling station before the IWC moratorium, is widely known as the 'town of whales,' complete with a Whale Museum, a Cetacean Research Institute (CRI), an annual whale festival, and most recently, a whale watching centre with an aquarium for dolphin shows. Most of all, it is famous for whale meat restaurants-in 2007 when the research was conducted, there were 28 in total, and all concentrated in one street.

\section{Methodology}

This study was largely carried during the summer of 2007 in four towns situated on the southeast coast of the Korean peninsula all with a strong connection with by-catch: Guryongpo, Yangpo, Jeongja, and Jangsaengpo. In 2010, follow-up interviews were conducted with some of the interviewees in order to reflect recent changes and update relevant data sets.

As most fishermen and the local communities are known to be apprehensive and, to a degree, suspicious of the conservation agenda surrounding by-catch, we decided against formal structured interviews and instead adopted a semi-anthropological research style which sought to build trust and understanding of working men not familiar with communicating with outsiders about a subject potentially loaded with legal and political implications. Time was therefore spent immersing the researcher in their world by undertaking a combination of interviews in informal surroundings, shared activities, and follow-up chats and conversations. These activities were supplemented by 
formal and social group meetings and get-togethers, with rapport and trust maintained with a series of telephone follow-ups and occasional meetings.

The interviews were conducted using a topic guide approach to allow the researcher to approach the interviews in a focused but flexible manner (Bernard 2006). Audio recording, where permitted, was conducted using a digital recording device to acquire a verbatim record of the conversations and to avoid unnecessary and potentially intrusive note-taking during the interview conversations. Consent was acquired from the respondents for storing and using the data for research on the condition of anonymity. Interviewees were deliberately chosen due to their special contribution, insight or position they held (Denscombe 2003). At the initial stage of the study, interviews with a wide range of stakeholders were largely unstructured to generate as many concepts as possible. As field research proceeded, emerging themes directed what data needed to be collected and from whom, therefore sampling became more purposeful and the interviews more structured, while retaining sufficient flexibility to allow new ideas to emerge. Some of the interviews with fishermen and local residents were conducted with other family members, neighbours or boat crew members present. This was largely due to interview setting, i.e., house, community centre, fishing boat, and provided useful additional information on certain topics or supplementary comments.

In total, data were collected from 31 in-depth interviews, involving 58 participants including fishing boat owners, fishing crew, restaurant owners, local enforcement officers, and representative of an environmental NGO (Table 1). At the initial stage, data were analysed line-by-line to build the basic concepts from discrete elements and concepts that shared common characteristics which could be categorised as a theme (Strauss and Corbin 1998). Themes that emerged from interviews were coded, compared, and grouped into categories and subcategories that helped explain by-catch. In the later phase of the analysis, data were reassembled through axial and selective coding, and rearranged by their relationships through constant comparisons (Glaser 1994). Apart from our interviews, we also used media reports as a supplementary source of information regarding the whale meat trade, such as the number of whale meat restaurants and estimated annual consumption because no official data were available.

\section{Results}

The interviews generated five themes and eleven subthemes (Table 2), described below. Supporting quotes are also given to illustrate a wider point and these are coded to protect the anonymity of the source (e.g., F is Fisherman; L is Local; $\mathrm{T}$ is Trade).

\section{Attitudes Towards Cetaceans and Cetacean Conservation}

Most local people were sympathetic to the notion of cetacean conservation, believing that humans should not drive any species to extinction and were aware of the threats to creatures such as whales with slow reproductive rates. However, all felt that cetacean meat was an important part of their food culture and there was a strong consensus that cetaceans were a resource that should be 'used' just like

Table 1 Sampling strategies

\begin{tabular}{|c|c|c|c|c|c|}
\hline Stage & Sampling strategy & Interest group & & No. of interviews & No. of interviewees \\
\hline \multirow[t]{5}{*}{1} & \multirow[t]{5}{*}{ Semi-random sampling } & \multirow[t]{2}{*}{ Local community } & Local fishers Non bycatcher & 2 & 7 \\
\hline & & & Local Residents (non-fisher) & 4 & 16 \\
\hline & & Police & Local police officer & 1 & 1 \\
\hline & & eNGO & & 1 & 1 \\
\hline & & Research Institute & & 1 & 1 \\
\hline \multirow[t]{5}{*}{2} & \multirow[t]{5}{*}{ Purposeful sampling } & \multirow[t]{3}{*}{ Local community } & Local fishers Bycatcher (Minke or small cetacean) & 4 & 6 \\
\hline & & & Former whalers & 1 & 2 \\
\hline & & & Restaurant owners & 2 & 2 \\
\hline & & Police & Local police officer & 2 & 2 \\
\hline & & Biologist & & 1 & 1 \\
\hline \multirow[t]{3}{*}{3} & \multirow[t]{3}{*}{ Purposeful sampling } & \multirow[t]{2}{*}{ Local community } & Local fishers Bycatcher (Minke only) & 3 & 6 \\
\hline & & & Restaurant owners - wholesalers & 2 & 2 \\
\hline & & Police & Police officer in investigation division & 3 & 3 \\
\hline \multirow[t]{2}{*}{4} & \multirow[t]{2}{*}{ Purposeful sampling } & Local community & Local fishers Illegal whalers & 2 & 6 \\
\hline & & Auction dealer & & 2 & 2 \\
\hline Total & & & & 31 & 58 \\
\hline
\end{tabular}


Table 2 Summary of themes

\begin{tabular}{|c|c|c|}
\hline No. & Theme & Sub theme \\
\hline \multirow[t]{2}{*}{1} & Attitudes about cetaceans and cetacean conservation & Attitudes towards cetaceans \\
\hline & & Attitudes towards other stakeholders and cetacean conservation \\
\hline \multirow[t]{2}{*}{2} & Socio-economic circumstances of fishermen & Income security \\
\hline & & Financial conditions and attitude towards bycatch \\
\hline \multirow[t]{2}{*}{3} & Bycatch economics & Supply and demand \\
\hline & & Market value of bycatch \\
\hline \multirow[t]{3}{*}{4} & Reasons of high cetacean bycatch & Increasing population of cetacean \\
\hline & & Fishing pressure \\
\hline & & Possibility of deliberate bycatch \\
\hline \multirow[t]{2}{*}{5} & Future management & Sustainable resource use \\
\hline & & Ecotourism as an alternative \\
\hline
\end{tabular}

other species, especially as the population of Minke whale and dolphin were believed to be increasing. Although it was understood that commercial whaling was illegal, the legitimacy of the whaling ban was questioned, and most people felt that Korean marine resources should be available for use by Koreans. Indeed, many thought it unfair that Minke whales in Korean waters could not be hunted, because they (mistakenly) believe that the same whales could be legally killed in Japanese waters under their scientific whaling scheme. By-catch was not considered a threat to whale populations and the issue was not taken seriously by any of the fishermen interviewed, so the possibility that their activities might be harmful to Minke whales was not even considered. There seemed to be strong support for the sale of by-catch, even among enforcement officers, with each whale landed an occasion for celebration built on a strong nostalgia for 'better days.'

Fishermen were more antagonistic towards small cetaceans (dolphins and porpoises) as those species could seriously disrupt fishing efforts, feeding on commercial species such as sardines and squid. A local fisherman confessed "Once you see dolphins, you get nothing that night. After all the efforts with lighting up lamps, waiting the whole night, and spending money on fuel, it is wasted when dolphins appear. I sometimes feel like bombing them" (F7). Although most fishermen had not experienced disturbance from Minke whales, they were also considered competitors as they feed on krill shrimp and anchovies which are prey of the fishermen's target species. Generally fishermen were very frustrated that their economic situation was being ignored by policymakers and this tended to taint their view about whale conservation. In the words of one local fisherman: "I understand the need of protection when whale populations are in danger, but now that they are plentiful, it is time for us to be protected" (F11).

There was a great deal of discontent about the IWC ban on whaling and very negative views about anti-whaling nations and environmental NGOs. Local people condemned anti-whaling western countries for insisting on unconditional protection of cetaceans, irrespective of their conservation status, and for ignoring the cultural and economic dimensions of whaling. One interviewee stated: "It is nonsense for them to stop us eating whale meat just because they do not eat it and they find whales and dolphins cute. They are the ones who used to kill countless whales just for blubber and abandon the best parts. But it is food for us and we do not waste it as they did. How dare they blame us?" (L16).

Furthermore, pointing to large scale whaling operations by Japan and Norway, the majority held that Koreans were less supported by their own government, which they assumed was due to 'weak-kneed diplomacy' by the government and their lack of influence on the international stage. Attitudes towards the Ministry for Food, Agriculture, Forestry and Fisheries (MIFAFF) were also negative, holding that the government failed to protect its own people's interests with respect to whaling and was not very supportive of small-scale fishermen generally. Also, some management measures were criticized as being unrealistic and government officials were regarded as remote and lacking in practical knowledge about the situation.

\section{Socio-Economic Circumstances of Fishermen}

Fishermen found it was becoming increasingly difficult to earn their livelihoods due to reduced catches and many were in debt despite working extremely hard. Various reasons for falling catches were offered including stock depletion with increased fishing effort; reduction in their fishing area following the Korean-Japanese Fisheries Agreement in 1998; disturbance by dolphins; and environmental changes (e.g., temperature, pollution). These views are generally supported by studies on coastal fisheries in 
Korea (Shin and Kim 2002; Chang, 2003), except there is no study on the impact of disturbance by dolphins. Following an open question, all fishermen agreed that stock depletion coupled with increased fishing effort were the most important major factors and interviewees well understood the 'vicious circle' of overfishing and its long term consequences. In the words of one fisherman: "We try to catch as many as possible so that we can earn more. Then the price goes down so we need to catch more, setting more nets and working longer. As it repeats, maintenance costs increase more and more and the stock gets depleted. We know it is bad for ourselves for the long term but what can we do?" (F10). While most fishermen were aware that this would eventually harm the marine ecosystem and their long-term livelihood, they found it hard to see how they could change this situation without an effective management system.

It was clear that by-catch provides fishermen with the potential of significant additional income. Landing a Minke was described as a 'fisherman's dream':"Of course I do dream about it.... Who would not like winning lotto when life is this tough?" (F2). This is confirmed by the fact that one large Minke, landed as by-catch, could generate income equivalent to $50 \%$ or more of average annual income (depending on the size of the business, the price of whale meat and size of the whale) (Figs. 1 and 3d). However, fishing crew who had first or second-hand experience of landing a Minke stated that in reality most of the money went to the owner by tradition: in the case of gill or trap netters, $50 \%$ goes to the owner, with the remainder split among the crew; with set netters, $100 \%$ of the revenue goes to the owner and the crew is only paid regular salary.

Although the issue of illegal whaling was difficult to raise directly due to its sensitive nature, most interviewees appeared to know that illegal whaling occurred, and the overall impression created was that illegal whaling, whether disguised as by-catch or direct hunting using harpoons or similar weapons, was understandable in light of the perceived abundance of whales and the poor socioeconomic status of fishermen due to lack of fish, sentiments neatly expressed by one fisherman: "Who would like to become a criminal? They hunt whales not because they are bad people or they can make a fortune, but because they suffer from decreasing income" (F3). Another interviewee blamed poor economic conditions: "Look around this place. What do you think the quality of my life is like? It's worst of the worst. My children didn't even go to university and are now working at a construction site. Fish catch is declining every day. I'm doing it (referring to illegal whaling) because that's the only thing I can do...... Imagine you have found a wild ginseng in the mountain. Would you not pick it up?" (F19). Some also believed that illegal whaling could, at least in part, be justified by government policy which allowed by-catch to be sold: "They [referring to government] are the boss of the gang. Why on earth do they sell confiscated whales? Why don't they just dump or burn the meat like other illegal goods? Why don't they arrest people who sell or buy the stolen goods? They are just bullying the weakest" (F20).

\section{By-Catch Economics}

The market for whale meat in South Korea is not monitored in a systematic, comprehensive way, making it difficult to assemble data on the supply and demand of whale products and the price. Therefore, time was spent during the interviews understanding the market for by-catch and securing price information. The vast majority of Minke by-catch are sold to 10 wholesalers, who buy whales at auctions organised by fishery cooperatives. An unknown, perhaps small, proportion of dolphins and other small cetaceans are privately sold or consumed directly by locals. Confiscated meat from illegal whaling, whether through active whaling with a harpoon, or whales landed as by-
Fig. 1 Price per unit length $(\mathrm{KRW} / \mathrm{cm})$ of Minke whale meat converted to 2010 real prices

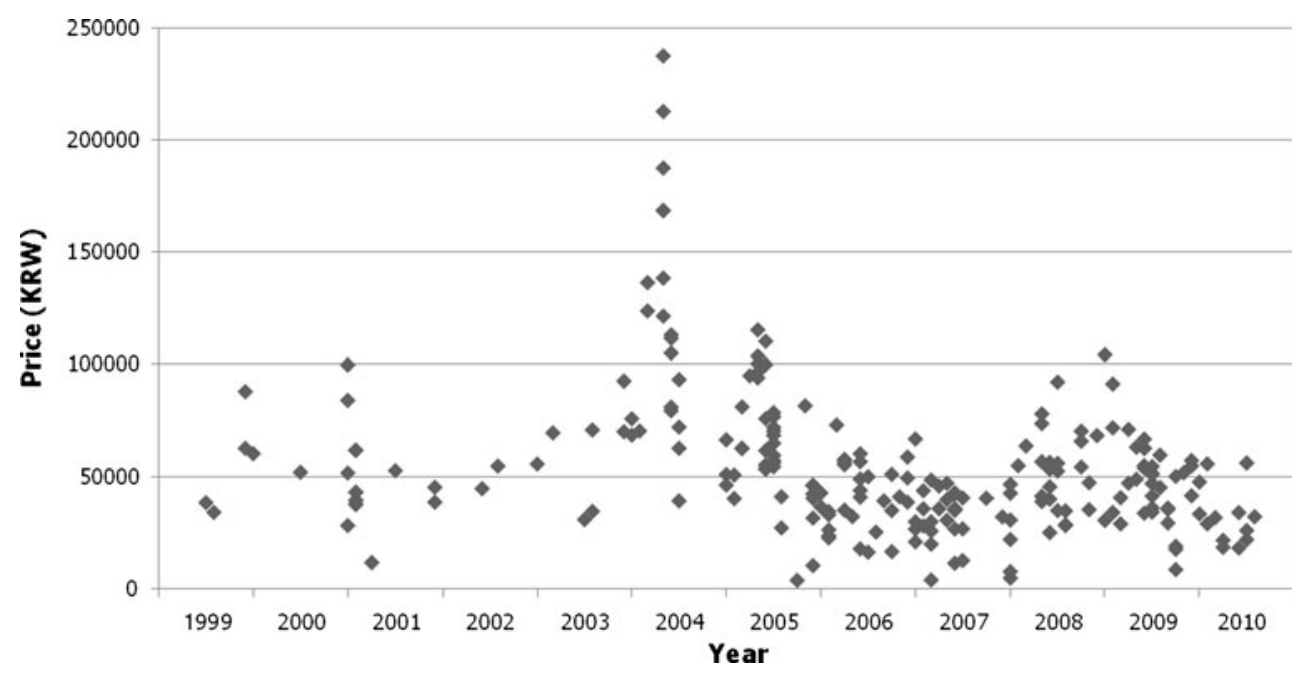


catch and declared illegal by KCG during the inspection, are also sold at these auctions, with revenues going directly to the National Treasury.

Most wholesalers run their own specialty restaurants, trading to both end consumers and other retailers and accounting for approximately $90 \%$ of Minke whale meat consumed (Dong A Ilbo 2006). Some whale meat is also sold to non-specialty restaurants that sell other foods, and to small food stalls that cluster around conventional street markets in Pohang and Busan. As the owners are not obliged to specify the type of food they serve it is not known how much whale meat is actually consumed, and there are no official figures on whale meat consumption. However, available evidence suggests that consumption may have increased from around 150 Minke before 2005 (Yeonhap News 2005) to 400-500 whales in 2010 (Busan Ilbo 2010; MBC 2010). This trend was confirmed by restaurant owners, the KCG and local fishermen, who all said that consumption had significantly increased over recent years. Furthermore, some interviewees particularly mentioned that supply, demand, and to a certain extent, price had recovered strongly following a 'crash' in the market due to the IWC moratorium. It was also remarked that consumption patterns had changed appreciably over the last 20 years, with whale meat consumed less as an 'everyday' item and more as a 'gourmet' product in restaurants due to significant improvements in the standard of living over that period.

By-catch prices peaked in 2004, with prices in excess of US $\$ 100,000$ for large specimens, but since then prices have fallen to one-third of this value. This is confirmed from price data covering the period 2000 to August 2010 collected from newspaper articles and verified from interviews and personal communications with other informants via e-mails or telephone. These data consisted of information on auction price for the whole whale, estimated whale length, and in some cases a comment on overall quality (freshness and maturity). These data were calculated as a price per unit length (KRW/cm) converted to 2010 real prices (Fig. 1). A few interviewees, including restaurant owners, suggested that the main reason for the rapid fall in price in the years after 2004 was a rapid escalation in illegal hunting activity following a major meeting of the IWC in Ulsan in 2005 which precipitated the strict enforcement of measures to restrict illegal hunting (Hankook Ilbo 2004).

The estimated number of specialty restaurants, which has been increasing, albeit with some fluctuations over time, reflecting increased availability of meat, also appears to be strongly influenced by government actions. For example, in 2004 the number of restaurants fell due to more intensive enforcement by KCG (Dong A Ilbo 2004), but in the last 2 years (2009-10), with active support from local government, 'whale tourism,' including dolphin shows, whale watching, and promotion of the annual whale festival, has stimulated consumption and the number of restaurants in Ulsan has increased dramatically (Ulsanpress 2010).

Apart from the prevailing supply and demand for whale meat, the price of by-catch is determined by quality, especially freshness, and to a certain extent blubber thickness and maturity (juveniles are less preferred). As whale meat spoils relatively fast due to body temperature, the period of time the whale stays in the water post-mortem is critical to value and the price of a Minke whale can vary by tens of thousands of US\$s depending on its freshness. According to one wholesaler: "Whales start to go bad $24 \mathrm{~h}$ after death. You can only sell blubber, fin or fluke after a couple of days of death. There is no point buying low quality products now as I have enough stocks in a freezer" (T2). For this reason, illegally hunted whales are preferred since these whales are killed and frozen immediately after death whereas by-catch could have stayed in the water for several days. However, despite being of better quality, illegal meat is sold up to $50 \%$ cheaper due to the risks involved according to our interviewees (e.g., F12 and T1) and other sources (e.g., SBS, 2008).

\section{High Cetacean by-Catch}

Many of the interviewees, especially fishermen, were convinced that high by-catch in Korean waters was due primarily to intensive fishing effort, rising Minke populations, and altered environmental changes. It was also suggested that the narrow continental shelf of the East Sea which is an important fishing ground for both fishermen and Minke whales, creates a natural 'catching ground.' The belief that cetacean populations were increasing was largely based on anecdotal tales circulating amongst local people, reinforced by newspaper stories. However, on deeper exploration, it was established that people were largely referring to dolphins and porpoises, and not Minke whales. According to one fisherman, referring to small cetaceans: "I used to see them once in a while when I started fishing about 10 years ago, but now every time I go to sea I see them. I sometimes think their number is higher than the fish I am after" (F1). When questioned specifically about Minke whale, they were less sure although some mentioned that Minke were seen more often now than in the 1990s. It was also apparent that many people simply assumed populations of Minke were larger because of the 20-year moratorium.

The only interviewee who believed that intentional bycatch was actually significant was a representative of an environmental NGO, believing that some fishermen would set nets deliberately in areas where whales were more likely to be caught. As evidence she cited the fact that some fishermen had caught whales or dolphins repeatedly. Furthermore, she claimed that it was an 'open secret' in 
the local community that some fisherman would deliberately drown an entangled whale. Although the fishermen we interviewed claimed that it was impossible to set nets deliberately to catch whales some did admit that drowning an entangled whale was tempting: "I would not chase whales for a living, but if I happen to find one in my net, nearly dead, I would put the net back and wait for it to die. It is a lot of money" (F2). Police interviewees also suspected that deliberate drowning may be occurring, but they were unable to establish this during visual inspection.

\section{Future Management}

There was strong support for an immediate resumption of commercial whaling operations among the local community. Fishermen in particular emphasized the urgent need of major culling operations against small cetaceans as they caused too much disturbance. In the case of Minke whales, with a few exceptions, interviewees believed that some form of limited whaling should be allowed to benefit the local community as it provided income to hard-pressed fishermen and would maintain the region's whaling culture. Most interviewees stressed that Minke whales should not be driven to extinction as they are an intrinsic part of the marine ecosystem which humans should protect in perpetuity. Strong sustainable management through the setting of quotas, reliable population monitoring and careful allocation of whaling permits, together with strengthened enforcement, would be required.
Alternatives to commercial whaling, such as ecotourism were raised, but fishermen and other local people doubted that whale watching alone would work. Their skepticism was based on the perceived randomness of actually seeing cetaceans, the lack of infrastructure for tourism in the region, and the reluctance of fishermen to switch to a new business. This negativity was also, in part, due to the fact that local people had been excluded from the discussions. (Since the interviews were conducted in 2007, whale watching has operated in Ulsan, and co-exists with an increasing number of whale meat restaurants.)

\section{By Chance or by Design?}

Local stakeholders suggest that the high incidence of by-catch in Korean waters is primarily associated with high whale abundance and more intensive fishing effort, but that deliberate by-catch through drowning or other means could be taking place. Although opinions differ regarding the magnitude of deliberate by-catch, a number of possible drivers were identified including strong support for a resumption of commercial whaling, deteriorating socioeconomic conditions and the prospect of large financial gain (Fig. 2). Furthermore, local people believed that deliberate by-catch and illegal whaling activities were understandable and, to a certain extent, legitimized by the hostility of the 'outside world' and neglect by their own government of the fishermen's situation.

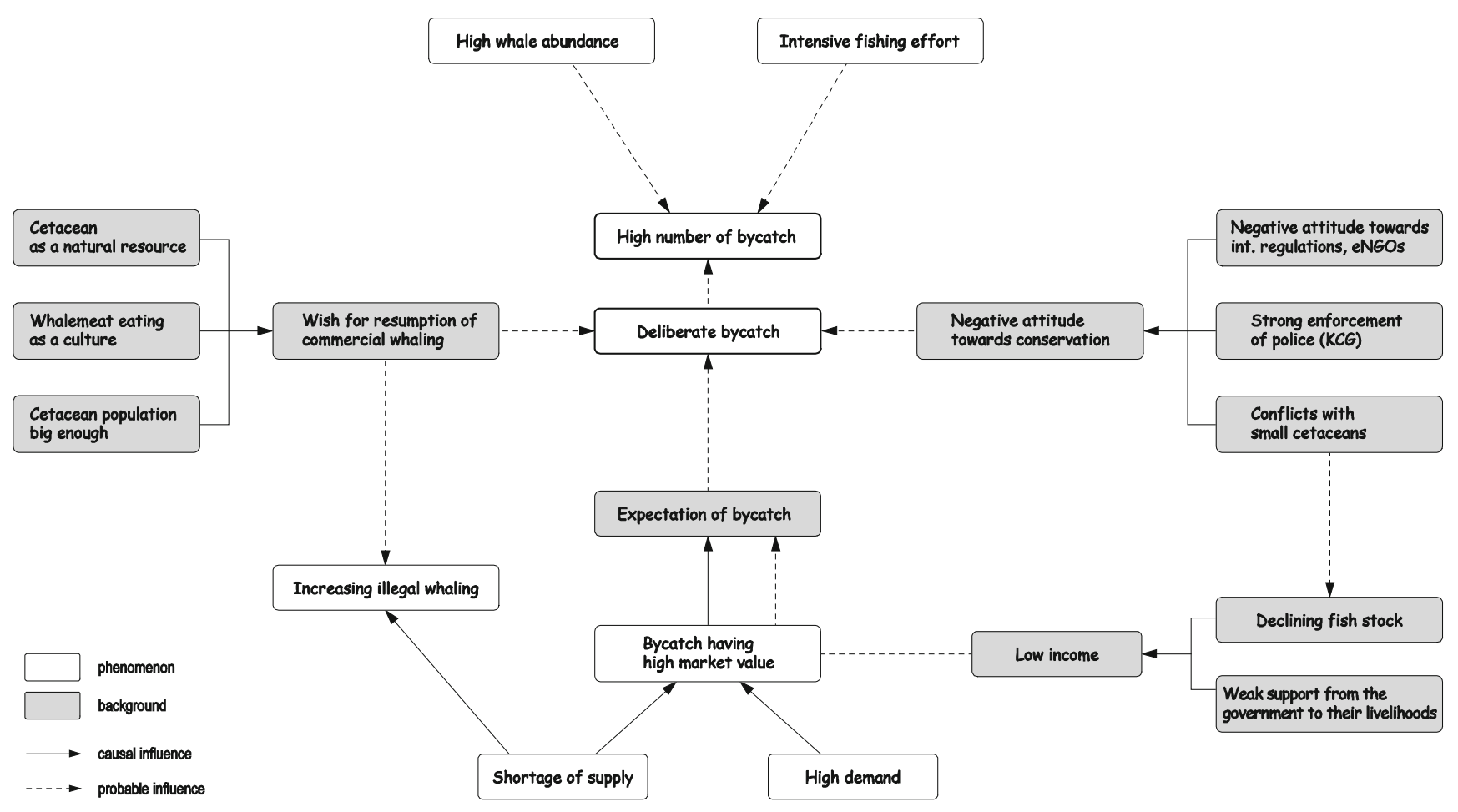

Fig. 2 Linkages between emerging themes 
764

Hum Ecol (2011) 39:757-768

In this section we examine what factors might be connected to the pattern of by-catch observed in the past $10-15$ years using available data. Figure $3 a$ presents Minke whale abundance data in the East Sea estimated from sighting survey results between 2000 and 2009 (An et al. 2010b). These abundance estimates are based on limited line survey data and are not consistent with the view of fishermen that the Minke population is increasing. Figure $3 \mathrm{~b}$ shows the total tonnage of fishing vessels

a

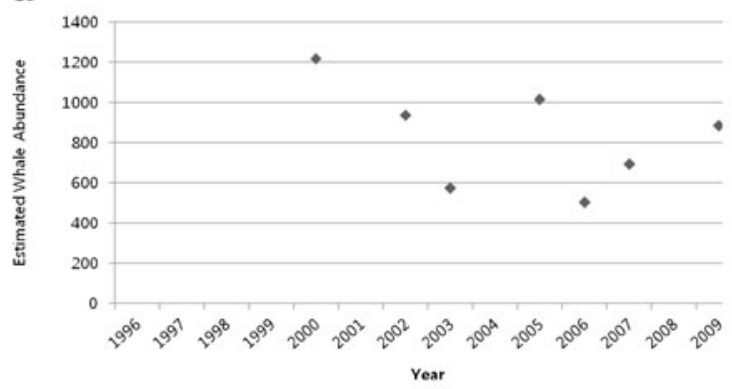

C

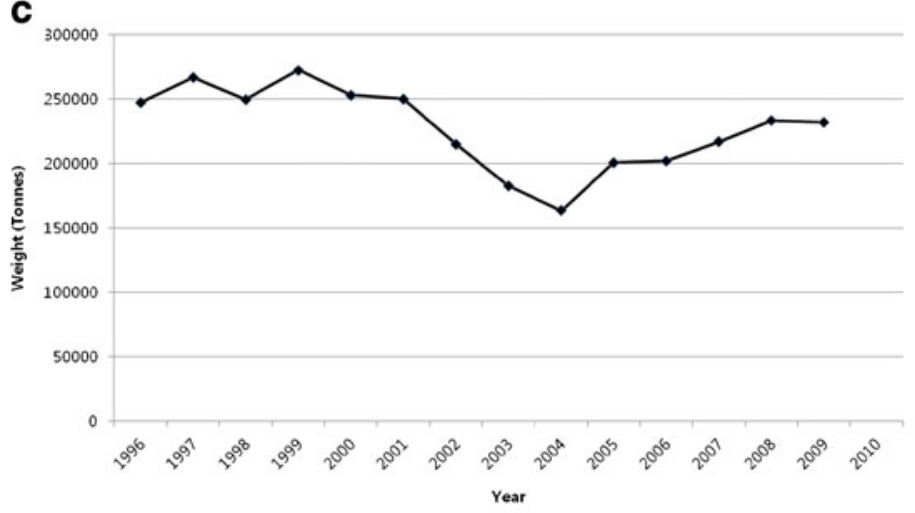

e

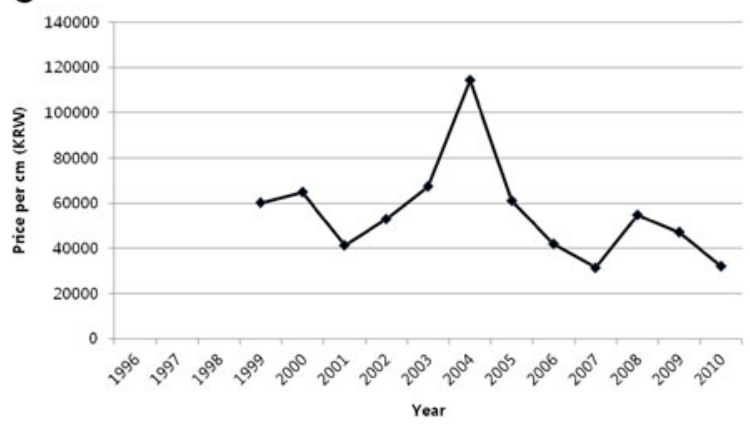

classified as gill net, fish pot and set net in offshore and coastal waters has declined over the last 15 years (Fishery Information Service 2010). According to Song et al. (2010) these net types account for $96.7 \%$ of 214 cetacean entanglements investigated between 2004 and 2007. Although this would also appear to conflict with the view of fishermen that fishing effort was intensifying, it may be because the government data do not include other measures of effort such as the number and length

b

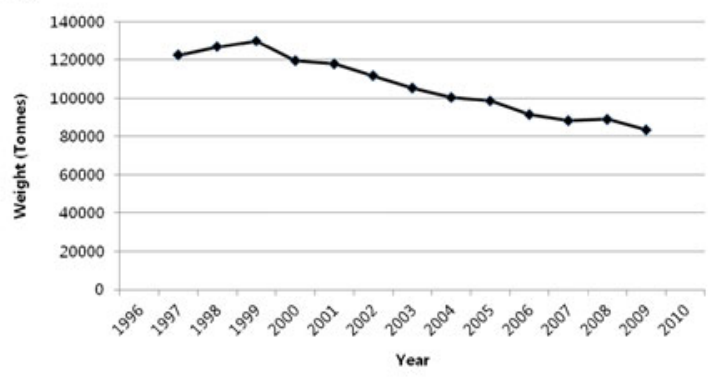

d
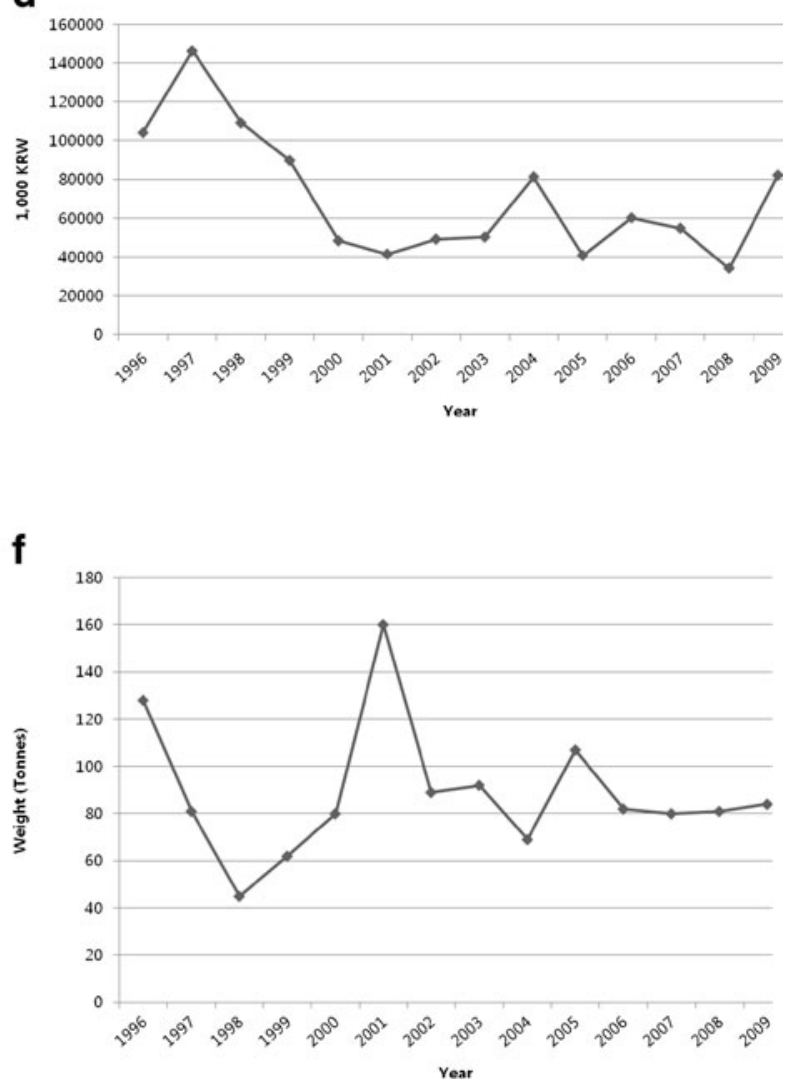

prices) for offshore fishing businesses using gear most likely to result in bycatch (gill net, fish pot in offshore and set net in coastal fisheries) sourced from Fisheries Economic Institute (2010). e Annual average real price (2010 prices) of Minke bycatch per $\mathrm{cm}$ sourced from media and from interviewee records. f Annual bycatch records of Minke Whales sourced from An et al. (2010a) and KCG

Springer 
of nets, and frequency of trips, etc. Figure $3 \mathrm{c}$ and $3 \mathrm{~d}$ show a long term decline in fish landings (Statistics Korea 2010) and average net real profit (2010 prices) of fishing businesses (Fisheries Economic Institute 2010) using gear most likely to result in by-catch, (although the profit data is only available for offshore vessels (gill net and fish pot) and coastal set net fisheries). This is consistent with views expressed by all our interviewees and indicates that the sector and the stocks are under considerable pressure. Figure $3 \mathrm{e}$ shows the annual average price of Minke by-catch sourced from media articles and Fig. $3 \mathrm{f}$ shows the annual by-catch records sourced from An et al. (2010a) and the KCG.

The complete data set spans a period of only 10 years hence it is not possible to apply appropriate multivariate statistical techniques. While there does not appear to be any obvious relationship between by-catch and any of the other datasets, there is a notable spike in the price of whale meat in 2004 which, according to our interviewees, was due to an acute supply shortage. In the following year by-catch numbers were very high, raising the possibility that prices in 2004 may have encouraged deliberate by-catch but this cannot be statistically explored due to the relatively short time-scale of the data sequence. The dramatic fall in price between 2005 and 2007 does not seem to have affected the by-catch harvest and can perhaps only be explained by significant changes in market dynamics. As many of our interviewees clearly stated that demand for Minke meat has been increasing, then this price fall can only have been brought about by an increase in supply (Fig. 4). With official by-catch landings in decline during these years, the shift in supply could only have arisen from: i) the sale of frozen meat stocks; ii) the illegal import of frozen, freshcaught Minke from Japan; and/or iii) illegal whaling by Korean fishermen.
The first seems unlikely as few businessmen would sell off their frozen stocks when prices are falling. Moreover, it is unlikely that significant volumes of frozen stock would be available in the period after 2004 because many stocks had been used up during the 'supply crisis' of that year with 10 out of 30 restaurants closing due to extreme shortages of meat (Dong A Ilbo 2004). Minke meat illegally imported from Japan was recently discovered for sale in a gourmet restaurant in Seoul (Baker et al. 2010). Although small scale of smuggling by the restaurant owner was involved in this case and there is little information on the scale of the illegal import trade. Some of our informants said they heard 'rumours' that significant stocks were illegally imported, but there have only been a few recorded cases of smuggling recorded in South Korea (Kang and Phipps 2000). Also, there are known to be surplus stocks of frozen fresh whale meat in Japan and better prices exist in South Korea for fresh whale products. For example, Tinch and Phang (2009) report that prices in 2006 in Japan were around US\$16 per $\mathrm{kg}$, compared to prices of up to US\$37/ $\mathrm{kg}$ in South Korea for confiscated fresh whale meat. Illegal hunting is potentially also a major source of meat based on verbal comments by our interviewees and previous studies on whale meat market in South Korea (Dalebout et al. 2002; Baker et al. 2006, 2007). Indeed, one interviewee reported that many restaurant owners would actually only buy token amounts of legal by-catch to cover up their primary illegal source and another confessed in a follow-up chat in 2010 that auction prices of by-catch are highly dependent on 'the illegal supply.' According to KCG, the numbers of illegally caught Minke whales have officially ranged from 2 to 15 per annum during the period 2004-2010; however, Segye Ilbo (2007) reports that the actual number may be four or five times higher than this and recent estimates have been in the region of 400 to 500 (Busan Ilbo 2010; MBC 2010).
Fig. 4 Suggested market dynamics of Minke whale meat in South Korea (2004-2010)

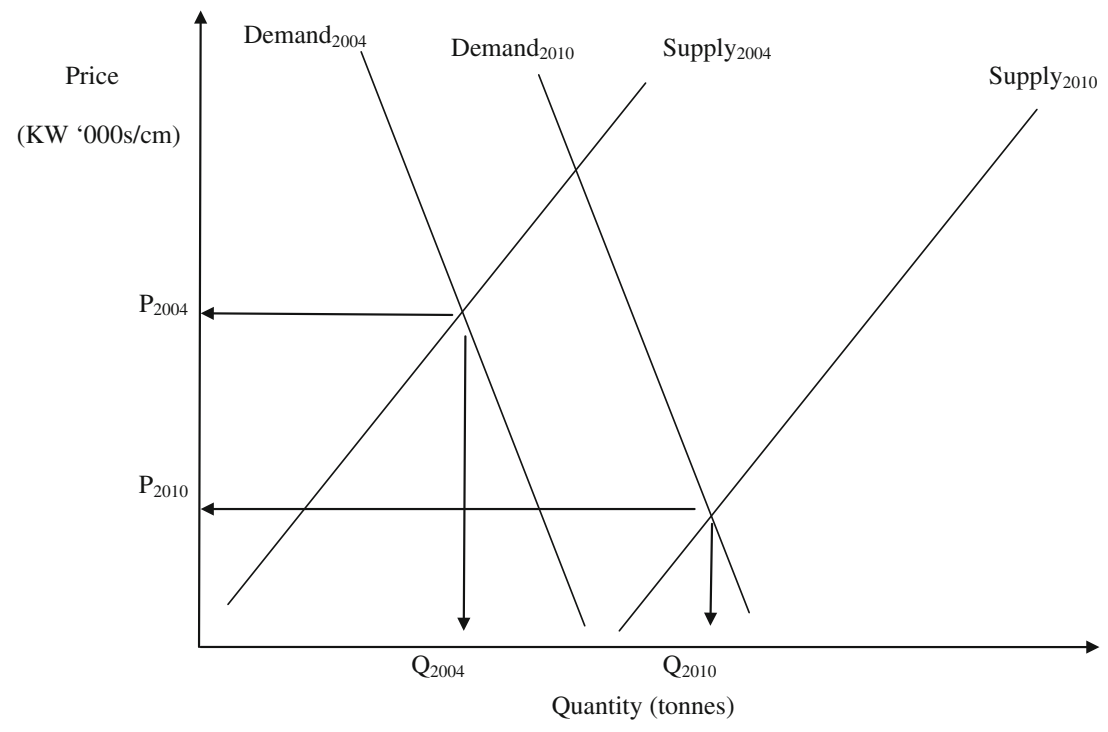


These larger numbers are more in line with our expectations and seem to be further substantiated by the discovery and arrest of illegal whalers and traders in March 2008 involving 90 Minke, and in June 2010 involving 120 Minke, (SBS 2008; KCG 2010). Illegal hunting on this scale would certainly be consistent with the significant fall in average price observed after 2004.

\section{Discussion and Conclusions}

Our research strongly suggests that deliberate by-catch is almost certainly taking place, but at an unknown level and that local attitudes to the issue are strongly influenced by conflicts between fishermen and cetaceans due to disturbance during fishing and competition for prey. Although current scientific data are inadequate for a reliable empirical investigation of the by-catch phenomenon, our conclusion arises from anecdotal accounts from a wide variety of interviewees, from a clear appreciation of the potential drivers such as declining business profits and strong economic incentives, and market data which suggest a link between the price of Minke meat and the level of bycatch harvest in the following year. Furthermore, price movements in recent years suggest that illegal whaling and/or illegal importation may be significant and there is indirect evidence from a range of sources, including the arrest of people involved in the illegal trade, to corroborate this view (Segye Ilbo 2007; SBS 2008; Busan Ilbo 2010; KCG 2010; MBC 2010).

In our view the South Korean regulations that permit commercial gain from Minke by-catch have effectively facilitated the development of an illegal trade due to the high price of whale meat. Based on our evidence, the illegal trade may, in fact, be more significant than the legal bycatch harvest. Given the intensity of local feeling, it is probably not politically feasible for the South Korean government to prohibit trade in by-caught whale meat because it provides hard-pressed fishermen with significant income at a time when catches are diminishing. In such circumstances we believe that the best immediate strategy will be to significantly improve the monitoring and management of the by-catch trade to reduce opportunities for illegal meat to be traded. Some measures to counteract illegal whaling such as certification of legally sourced whale products (i.e., by-caught and confiscated whales) and mandatory DNA sampling (MIFAFF 2010) have been implemented since January 2011, but we believe it is also necessary to introduce systematic monitoring of whale meat in restaurants and mandatory reporting of quantities supplied and consumed. Together with higher penalties these measures should reduce illegal whaling activities.

Another future option that the government might consider would be the introduction of a tax on the sale of whale products at auction. Assuming whale meat is a normal good, a by-catch tax would increase the price of meat and provide a flexible and responsive mechanism that can control the financial incentive for intentional by-catch should this be considered appropriate (Milner-Gulland and Clayton 2002; Rowcliffe et al. 2003; Cowlishaw et al. 2005; Crookes et al. 2005). The tax rate itself would be a political decision, and we would propose that revenues raised should be reinvested in a local community fund and used to provide fishermen with equipment such as 'pingers' which will help avoid accidental and costly whale entanglements with fishing nets. Given there are differing views and insufficient data about whale abundance, the tax is a flexible mechanism which could be set very low if whales are abundant and high should the population be deemed at threat of extinction.

In some respects the existence of a legal outlet for bycaught whale products provides the government with an opportunity to develop a sustainable management regime for cetacean populations that could ensure the future survival of the whale population and the good will and wellbeing of fishermen through a combination of economic incentives and regulation. Harsher measures, such as a complete ban, would risk driving the trade underground with all the problems associated with illegal, unreported, and unregulated (IUU) fishing activities.

We have here examined local rationales and practices underlying whaling activities and consumption. We show that Minke conservation is highly contested in terms of political, economic and cultural legitimacy, with local values and knowledge in direct conflict with the interpretation of the available scientific data by conservationists. More research will certainly be helpful, but we feel confident that our approach to understanding the issue, which uses analysis of price movements and a combination of both qualitative and quantitative methodologies, can has shed light on a complex, multifaceted and contentious conservation issue.

\section{References}

An, Y. R., Choi, S. G. and Moon, D. Y. (2010a). A review on the status of bycatch minke whales in Korean waters. Paper presented to the IWC Scientific Committee (SC/62/NPM19). Available from the IWC.

An, Y. R., Choi, S. G., Moon, D. Y. and Park, K. J. (2010b). A review of abundance estimates of common minke whale using the sighting surveys conducted in subareas 5 and 6 by Korea from 2000 to 2009. Paper presented to the IWC Scientific Committee (SC/62/NPM16Rev.). Available from the IWC.

Baker, C. S., Lukoschek, V., et al. (2006). Incomplete reporting of whale, dolphin and porpoise 'bycatch' revealed by molecular monitoring of Korean markets. Animal Conservation 9: 474-482. 
Baker, C. S., Cooke, J. G., et al. (2007). Estimating the number of whales entering trade using DNA profiling and capturerecapture analysis of market products. Molecular Ecology 16 (13): 2617-2626.

Baker, C. S., Steel, D., et al. (2010). Genetic evidence of illegal trade in protected whales links Japan with the US and South Korea. Biology Letters 2010(6): 647-650.

Barlow, J., and Cameron, G. A. (2003). Field experiments show that acoustic pingers reduce marine mammal bycatch in the California drift gill net fishery. Marine Mammal Science 19: 265-283.

Bernard, H. R. (2006). Research methods in Anthropology: Qualitative and quantitative approaches, 4th ed., Altamira Press.

Busan Ilbo (2010). War against illegal whaling with the purpose of receiving whaling quotas. $21 \mathrm{Jul}$ 2010, Busan Ilbo (local media), R oK. Retrieved 11 Nov 2010 from http://news20.busan.com/ news/newsController.jsp?subSectionId $=1010020000 \&$ newsId $=20100721000058$.

Chang, H. Y. (2003). Analysis on the Present Business States of Coastal and Off-shore Fisheries by Type of Fishery. Studies on Education of Fisheries and Marine Sciences 15(2): 166-175.

Cowlishaw, G. C., Mendelson, S., et al. (2005). Evidence for postdepletion sustainability in a mature bushmeat market. Conservation Biology 19: 139-149.

Crookes, D. J., Ankudey, N., et al. (2005). The value of a long-term bushmeat market dataset as an indicator of system dynamics. Environmental Conservation 32: 333-339.

Dalebout, M. L., Lento, G. M., et al. (2002). How many protected minke whales are sold in Japan and Korea? A census by microsatellite DNA profiling. Animal Conservation 5: 143-152.

Denscombe, M. (2003). The good research guide: for small-scale social research projects, 2nd ed. Open University Press, Buckingham.

Fisheries Economic Institute (2010). Fisheries Management Research. Search available from the website of National Federation of Fisheries Cooperatives (http://fei.suhyup.co.kr/).

Fisheries Information Service (2010). Fishing vessels statistics. Search available from the website of Fisheries Information Service (http://www.fips.go.kr/).

Glaser, B. G. (1994). The Constant Comparative Method of Qualitative Analisys. In More Grounded Theory Methodology: A Reader., Sociology Press.

Goto, M., and Pastene, L. A. (1997). Population structure in the western North Pacific minke whale based on an RFLP analysis of the mt DNA control region. Rep. IWC 47: 531-538.

Greenpeace International (2005). Korea's Minke whales-sliding into extinction. Media briefing, Retrieved 15 Dec 2006, from http:// www.greenpeace.org/raw/content/international/press/reports/ korea-s-minke-whales-slidin.pdf.

Hall, M. A., Alverson, D. L., and Metuzals, K. I. (2000). Bycatch: Problems and solutions. Marine Pollution Bulletin 41: 204-219.

Hankook Ilbo (2004). Crying at shortage of whale meats, 30 May 2004, Hankook Ilbo (National media), Republic of Korea. Retrieved 5 May 2007 from http://news.hankooki.com/ArticleView/ArticleView. php?url=society/200405/h2004053020073043380.htm\&ver=v002.

Hwang, S. Y., and Moon, M. D. (1984). Bangudae. Dongguk University Press, Seoul.

Dong A Ilbo (2004). No whale meat, no whale festival. 25 Mar 2004, Dong A Ilbo (National media), Republic of Korea. Retrieved 10 Aug 2007 from http://news.donga.com/3/all/20040325/8043598/1.

Dong A Ilbo (2006). "Whales in the East sea, scared of fishing nets." 4 Apr 2006, Dong A Ilbo (National media), Republic of Korea. Retrieved 11 Dec 2010 from http://news.donga.com/3/all/ 20060404/8291982/1.

IWC (1997). Report of the scientific committee, Annex J: Report of the working group on North Pacific minke whale trials. Rep. IWC 47: 203-226.
IWC (2009). Report of the Scientific Committee, Annex J: Report of the working group on estimation of bycatch and other humaninduced mortality. Retrieved 6 Dec 2010 from http://iwcoffice. org/_documents/sci_com/SCRepFiles2009/Annex\%20J\%20-\% 20Final-sq.pdf.

Kang, S., and Phipps, M. (2000). A survey of whale meat markets along South Korea's coast. TRAFFIC East Asia, Hong Kong.

KCG (2010). Roundup of a gang of whalers and whale meat distributors on the East coast. Media briefing, Retrieved 7 Nov, 2010 from http://www.korea.kr/newsWeb/pages/search/search. jsp?dquery $=\% \mathrm{~EB} \% 8 \mathrm{~F} \% 99 \% \mathrm{ED} \% 95 \% \mathrm{~B} 4 \% \mathrm{EC} \% 95 \% 88+\% \mathrm{EC} \%$ 9D $\%$ BC $\%$ EB $\% 8 \mathrm{C} \% 80+\% \mathrm{~EB} \% \mathrm{~B} 0 \% 8 \mathrm{D} \% \mathrm{ED} \% 81 \% \mathrm{AC} \% \mathrm{EA} \%$ В3\%A0\%ЕB $\% 9 \mathrm{E} \% 98+\% \mathrm{~EB} \% \mathrm{~B} 6 \% 88 \% \mathrm{~EB} \% \mathrm{~B} 2 \% 95 \% \mathrm{ED} \% 8 \mathrm{~F}$ $\% \mathrm{AC} \% \mathrm{ED} \% 9 \mathrm{~A} \% 8 \mathrm{D} \&$ collection $=\&$ chk $=$ true.

KFEM (2005). Sanctuary or Cemetery? Choosing a future for Korea's oceans. Media briefing, Retrieved 7 Jan, 2007, from http://kfem.or. $\mathrm{kr} / \mathrm{bbs} / \mathrm{view}$.php? $\mathrm{id}=$ whale news\&page $=1 \& \mathrm{sn} 1=\& \operatorname{divpage}=1$ $\& \mathrm{sn}=$ off $\& \mathrm{ss}=$ on $\& \mathrm{sc}=$ on $\&$ select $\_$arrange $=$headnum $\&$ desc $=$ asc\&no $=3$.

Kim, Z. G. (1999). Bycatch of Minke whales in Korean waters. Journal of Cetacean Research and Management 1(Suppl): 98 100.

Lewison, R. L., Crowder, L. B., Read, A. J., and Freeman, S. A. (2004). Understanding impacts of fisheries bycatch on marine megafauna. Trends Ecol. Evol. 19: 598-604.

Lopez, A., Pierce, G. J., Santos, M. B., Gracia, J., and Guerra, A. (2003). Fishery bycatches of marine mammals in Galician waters: results from on-board observations and an interview survey of the fishermen. Biological Conservation 111: 25-40.

MacMillan, D., and Phillip, S. (2010). Can Economic Incentives Resolve Conservation Conflict: The Case of Wild Deer Management and Habitat Conservation in the Scottish Highlands. Human Ecology 38(4): 485-493.

MBC (2010). Illegal whaling rampant... fishermen calling for culling, 28 July 2010, MBC (National media), Republic of Korea. Retrieved on 4 Nov 2010 from http://imnews.imbc.com/replay/ nwtoday/article/2667595_5782.html.

MIFAFF (2010). New changes in cetacean management, Media briefing, 12 Aug 2010, Retrieved 28 Aug 2010 from http://www. korea.kr/newsWeb/pages/brief/partNews2/view.do?toDate $=\&$ fromDate $=\&$ currentPage $\&$ dataId $=155667802 \&$ siteName $=$.

Milner-Gulland, E. J., and Clyton, L. M. (2002). The trade in wild pigs in North Sulawesi, Indonesia. Ecological Economics 42: 165-183.

Ministry of Food, Agriculture, Forestry, and Fisheries (2009). "Notification about whaling ban", Notification No. 2009-113.

Morizur, Y., Berrow, S. D., Tregenza, N. Y. C., Couperus, A. S., and Pouvreau, S. (1999). Incidental catches of marine mammals in pelagic trawl fisheries of the northeast Atlantic. Fisheries Research 41: 297-307.

Read, A. J., Drinker, P., and Northbridge, S. (2006). Bycatch of Marine Mammals in U.S. and Global Fisheries. Conservation Biology 20(1): 163-169.

Rowcliffe, J. M., Cowlishaw, G., et al. (2003). A model of human hunting impacts in multi-prey communities. Journal of Applied Ecology 40(872): 889.

SBS (2008). Illegally killed and sold whale meat for 90 whales caught by the police, 18 Mar 2008, SBS (National media), Republic of Korea. Retrieved 26 Oct 2010, from http://news.sbs.co.kr/ section_news/news_read.jsp?news_id=N1000391267.

Segye Ilbo (2007). "Illegal whaling methods getting increasingly sophisticated", 18 Jun 2007, Segye Ilbo (National media), Republic of Korea. Retrieved 10 Aug 2007 from http://www.segye.com/ Articles/News/WholeCountry/Article.asp?aid=20070618001685 $\& \operatorname{ctg} 1=01 \& \operatorname{ctg} 2=00 \& \operatorname{subctg} 1=01 \& \operatorname{subctg} 2=00 \& \operatorname{cid}=010107010$ $0000 \&$ dataid $=200706181325000079$. 
Shin, Y. T., and Kim, S. (2002). Directions for the Improvement of Coastal Fisheries Management. The Journal of Fisheries Business Administration 33(1): 69-83.

Song, K.-J., Kim, Z. G., Zhang, C. I., and Kim, Y. H. (2010). Fishing gears involved in entanglements of minke whales (Balaenoptera acutorostrata) in the East Sea of Korea. Marine Mammal Science 26: 282-295 doi:10.1111/j.1748-7692.2009.00340.x.

Statistics Korea (2010). Survey of fish landing trends. Search available from the website of Korean Statistical Information Service (http://kosis.kr/).

Strauss, A., and Corbin, J. (1998). Basics of qualitative research: Techniques and procedures for developing grounded theory, 2nd ed. Sage Publications, Inc, California.

Tinch, R. and Phang, Z. (2009) Sink or Swim: The Economics of Whaling Today. A Summary Report produced by WWF and WDCS Based on a study by Economics for the Environment Consultancy (eftec). Retrieved 1 Sep 2010 from http://assets.panda.org/down loads/economics_whaling_summ_report_final.pdf.
Trippel, E., Strong, M. B., Terhune, J. M., and Conway, J. (1999). Mitigation of harbor porpoise (Phocoena phocoena) bycatch in the gillnet fishery in the lower Bay of Fundy. Canadian Journal of Aquatic Science 56: 113-123.

Ulsan Metropolitan city (2003). Studies in preservation measures for Petroglyphs of Bangudae. Ulsan Metropolitan city, South Korea.

Ulsanpress (2010). Lifting whaling ban to stop the side effect of illegal whaling, 11 Jul 2010, Ulsanpress (Local media), Republic of Korea. Retrieved 18 Oct 2010 from http://www.ulsanpress.net/ news/articleView.html?idxno=56869.

Wade, P. R., Leaper, R., Kasuya, T. and Double, M. (2010) Factors to be considered when using abundance estimates for North Pacific minke whales. Paper presented to the IWC Scientific Committee (SC/62/NPM14Rev.). Available from the IWC.

Yeonhap News (2005). 150 whales consumed annually. 2 Feb 2005, Yeonhap News (National media), Republic of Korea. Retrieved 18 Jun 2007 from http://news.naver.com/main/read.nhn? mode $=$ LSD\&mid $=$ sec\&sid $1=100 \&$ oid $=001 \&$ aid $=0000902769$. 